Arhe XVII, 33/2020

UDK 179

DOI https://doi.org/10.19090/arhe.2020.33.189-219

Originalni naučni rad

Original Scientific Article

SPYRIDON STELIOS ${ }^{1}$

National Technical University of Athens, Department of

Humanities, Social Sciences and Law, Greece

KOSTAS THEOLOGOU ${ }^{2}$

National Technical University of Athens, Department of

Humanities, Social Sciences and Law, Greece

SIMONI ILIADI ${ }^{3}$

National Technical University of Athens, Department of

Humanities, Social Sciences and Law, Greece

ELENI MANOLAKAKI ${ }^{4}$

National and Kapodistrian University of Athens, Department of

History and Philosophy of Science, Greece

\title{
ARGUMENT, KNOWLEDGE AND ETHICS: UNDERSTANDING CORE CONCEPTS IN PHILOSOPHY BY AN EMPIRICAL STUDY ON GREEK UNIVERSITY STUDENTS
}

\begin{abstract}
An empirical study was conducted measuring the degree to which Greek university students' understanding of core philosophical concepts (that is, 'argument', 'knowledge' and 'ethics') has been shaped by the material taught in the classroom. The extent of this transition from pre-instructional conceptions to textbook formulations has been investigated through the use of a new questionnaire. Findings indicate that generally, students retain their pre-
\end{abstract}

\footnotetext{
${ }^{1}$ Author's e-mail address: stelioss@mail.ntua.gr

2 Author's e-mail address: cstheol@mail.ntua.gr

3 Author's e-mail address: siliadi@mail.ntua.gr

${ }^{4}$ Author's e-mail address: manolaka@phs.uoa.gr
} 
theoretical understanding of these terms. Within this framework, some formal definitions are closer to common sense (e.g. 'ethics') and some others aren't (e.g. 'knowledge'). Furthermore, the role of intuitions in this process is been evaluated, leading to the ascertainment that previous philosophical encounters seem to play a crucial role in determining actual understanding.

Keywords: pre-instructional conceptions, philosophy learning, philosophy teaching, intuition

\section{INTRODUCTION}

A key problem in teaching Philosophy is the successful assimilation by students of the basic philosophical concepts. This paper examines the findings of an empirical study about undergraduate and postgraduate philosophy students and their understanding concerning certain core concepts ('argument', 'knowledge' and 'ethics') as standardly taught in philosophy courses and presented in textbooks. The participants in the study were students that took either a compulsory Philosophy in Faculties of Philosophy or an optional Philosophy in other universities. We examined whether and under what (pre)conditions students are making a transition from pre-instructional conceptions (preconceptions or intuitive, everyday, common-sense conceptions) to textbook or formal formulations. The study also explored students' intuitions about these key concepts. The specific objective was to investigate how and to what extent academic teaching enhances their understanding of the subject.

\section{THEORETICAL BACKGROUND}

Several papers have dealt broadly with this issue and their findings have been taken into account both when constructing the questionnaire and formulating the research questions (see Sheppard and Gilbert, 1991; Salzberger, 1997; Weinberg et al., 2001; Alauddin \& Ashman, 2014; Wortham, 2015, Iliadi et al., 2019).

Sheppard and Gilbert (1991) found that students' conceptions of knowledge are influenced by how historical, philosophical, analytical and personal perception is structured and presented within university departments. There is, thus, a relationship between historical and 
philosophical studies, the methods of teaching them, and the development of student epistemological notions. Weinberg et al. (2001) conducted a series of experimental studies on epistemic intuitions. In response to the analytic tradition, the researchers highlighted how students intuitionally conceive applications of the concept of knowledge. Wortham (2015) considers Philosophy teaching as a way to clear away assumptions that seem to limit people's view on social issues. In this context, philosophical accounts of knowledge and identity offer conceptualizations that open new pathways for thought and action.

Nevertheless, the discussion has focused primarily on learning/teaching concepts of science. This paper attempts to broaden the discussion by examining the application of the theory of conceptual change to learning/teaching of philosophy and more specifically to certain basic philosophical concepts. As Murphy \& Alexander note: "It would seem that the conceptual change research would be enriched by stepping outside of this scientific "comfort zone" to investigate the change process in a range of academic domains, including those for which more data-based or justifiable outcomes are more difficult to substantiate" (Murphy \& Alexander, 2008, p. 597).

\subsection{Conceptualization ['argument', knowledge', 'ethics']}

Within the educational process, understanding of basic theoretical terms is particularly significant. If students and/or teachers seek to reach a common understanding on the way concepts are defined, they must be responsive to others' individualized use of terms, and this seems especially important in education. Paraphrasing an example used by Laverty (2009, p. 37) it could be argued that philosophy students will seek to deepen their understanding of the term 'knowledge' by listening to their philosophy professor speak about 'knowledge', and respectively the professor will seek to revisit her 'thin' concept of 'knowledge' to awaken and refine her students' awareness of its role in Philosophy. Within this process, it is crucial to also investigate the way students employ concepts.

More specifically, Laverty (2009) refers to the "distinction between concepts employed at first-order (our ordinary language use), and second- 
order conceptual clarification. The latter is characterized as the 'spectatorial mapping' by philosophers 'of concepts employed at the first order" (see Cato, 1987, p. 35 as cited in Laverty 2009, p. 29). Philosophers are capable of (and responsible for) identifying the logically necessary (and sufficient) conditions of our ordinary language-use. They "clarify the distinctions that our words were developed to designate...." (Laverty, 2009, p. 30).

A further distinction might be drawn between novices (beginners) and experts in Philosophy. On this Rusanen et al. (2008) have shown that novices' perception of philosophical concepts differs from that of experts. Of course, there is little consensus among researchers as to the nature of these differences, and also as to the specific states of the corresponding belief systems. For instance, some argue that they are poorly organized systems; internally inconsistent, fragmented and non-coherent (DiSessa, 1993).

Other researchers argue that the belief systems of novices are coherent, featuring the basic properties of scientific theories (Vosniadou \& Brewer, 1992 as cited in Rusanen et al., 2008, p. 64). But Science and Philosophy do not evolve in the same or parallel ways. As Rusanen et al. (2008) note in the field of natural science, cognitive conflicts emerge when a belief system comes up against counterexamples based on empirical data and observations in the world. Instead, Philosophy aims to reveal implicit commitments, clarify ambiguous positions, and at the same time clarify the relationship between concepts and beliefs. In many cases, therefore, philosophical theories do not relate to an independently observable structure of the world. Thus, in philosophy education, it is difficult to delineate the efficacy of the teaching methods. And this is mostly because a student's cognitive conflicts do not arise from the confrontation of her perceptions and empirical observation (Rusanen et al., Ibid, p. 65). So, the starting point of the learning process is any commonsense theory people have developed before instruction. Successful learning implies the internalization of a philosophical theory and a reconstruction of one's theoretical outlook on a subject. (Note 1)

\subsection{The Role of Intuitions}

Methodologically, this research falls within the framework of experimental philosophy. That is why, in our view, how students engage and 
understand these basic philosophical concepts, inevitably refers to their relevant intuitions, i.e. mental states (which might be beliefs or spontaneous judgments) in which a proposition seems true (Pust, 2019). Of course, the wide range of literature on intuitions compels us to concentrate on one aspect and particularly in what is called application intuitions. An introduction to this kind of intuitions is presented by Goldman (2007). Application intuition is, namely, just what anyone would say if asked her opinion. As noted by Goldman (2007, p. 2) "the propriety of saying or not saying something took the place of having an intuition; the matter was described in terms of speech inclinations rather than mental episodes. Nonetheless, the epistemological status of these inclinations or episodes played the same role in philosophical methodology. Each was invoked as a crucial bit of evidence for the philosophical 'facts' in question."

Application intuition is identified as the central type of philosophical intuition. It is about how cases are to be classified, or whether various categories or concepts apply to selected cases (see also Jackson, 1998; Koutoungos, 2008). We believe that this kind of intuition is, to a great extent, associated with philosophy teaching. In a philosophy class, understanding is gleaned from examples, counterexamples and clarification of basic terms through the verbal interaction between teacher and students. And that is why we chose to examine this kind of intuition.

\section{METHOD}

The following sections present the sampling method, data collection and the way these queries had been addressed.

\subsection{Population and Sample}

The study involved a total of 731 undergraduate and graduate students who attended Philosophy courses in the academic year 2014-15 in six Greek universities: University of Athens (UOA), National Technical University of Athens (NTUA), Hellenic Open University (HOU), University of Crete, University of Patras and University of Ioannina. All courses were taught in the Greek language. All students agreed to participate in the survey 
with the permission and/or the encouragement of the lecturer. Availability sampling was used due to easy accessibility of the subjects to investigators. Furthermore, this sampling method is popular in surveys among students enrolled in lecture classes. (Note 2)

Besides, students' agreement to participate was freely given and the process was abided by the IRB's Human Subjects Protection Tutorial (Note 3). Especially, as far as the informed consent process is concerned, the whole procedure complied with the IRB's principles of Information, Comprehension and Voluntariness of the subjects.

Methodologically, we defined as novices the undergraduate students of the first semester. Naturally, this status loses its significance by the year of studies. The later the semester, the greater the expertise of every student.

The three concepts and associated theories were taught in the classroom through the use of examples, counterexamples and conceptual clarification. As far as the theoretical/textbook definitions are concerned, we chose the following: 'argument' is (or consists of) 'at least one premise and one conclusion' (Baggini and Fosl, 2010), 'knowledge' is 'justified true belief' (Duke et al., 1995) and 'ethics' is 'behaviour under a system of values' (Churchill, 1999). These specific selections were made because, according to exploratory discussions with researchers and lecturers, they seem to cover the minimum conceptual specifications in any syllabus.

\subsection{Research Questions}

Within the above mentioned theoretical framework, one main research question with two corresponding sub-questions were put forward. A: Are students of Philosophy distinguishing core concepts such as 'argument' 'knowledge' and 'ethics' from their everyday language use, thereby associating them more with their theoretical definitions?

A1: What are the preconditions for this transition/distinction? (Note 4)

A2: What do students' answers tell us about the nature and shaping of their intuitions about these concepts? Does early exposure to philosophy play a role? 


\subsection{Collecting Data}

A questionnaire was formulated and used as a data collection instrument. It was designed as short, since 'short' is considered that of which the filling time is not more than 45 minutes (see Herzog and Bachman, 1981). To achieve content validity, i.e. to make sure that the selected measurement scale is measuring the understudied phenomenon (Salkind, 2007, p. 181), we followed the theoretical guidelines derived from discussions with colleagues. The relevant questions in the questionnaire and the corresponding answers are presented in the Appendix.

The final form of the questionnaire did not include open-ended questions to avoid turning the questionnaire to a kind of a test checking philosophical adequacy. We are aware of the fact that measuring such understanding using questionnaires that did not include open-ended questions might limit the ability participants had in being able to express any further complex and subtle understanding they might have gained over the course of their philosophy classes. Nevertheless, we chose close-ended questions to facilitate students in their answers and also facilitate coding and the statistical processing of responses. Finally, for the protection of personal data (privacy) an exclusive code was requested by every participant instead of her/his name.

\section{RESULTS - DISCUSSION}

As expected, most participants' age was between 18-24 years old (84\%). As far as the gender distribution, almost $74 \%$ of philosophy students are women and $25 \%$ are men (1\% of students did not identify their gender but this is statistically irrelevant). To investigate whether this women/men ratio is maintained as specialization and level of study progresses, we collected additional data from the registrar's office of each department concerning the gender distribution at the undergraduate, major and postgraduate level. From these data, two interesting findings emerged.

The first is that out of the 11,964 registered Philosophy students in Greece 8,816 (74\%) are women and 3,148 (26\%) are men. The fact that the percentages of the entire population, as a whole, are almost identical to those already found in our sample ( $74 \%$ women $-25 \%$ men) shows that although 
our sampling was based on the available subjects, it is - at least in terms of gender - representative.

The second interesting finding, although partly expected, is that the number of female students of Philosophy decreases as the specialization and level of study progresses. As shown in Figure 1, while the percentage of male undergraduate students at Philosophy is only $26 \%$, that increases to $31 \%$ in the undergraduate academic option of Philosophy (major). More specifically, about $20 \%$ of undergraduate male students choose Philosophy compared to a nearly $13 \%$ of women. At the postgraduate level, the percentage of male students reaches $39 \%$.

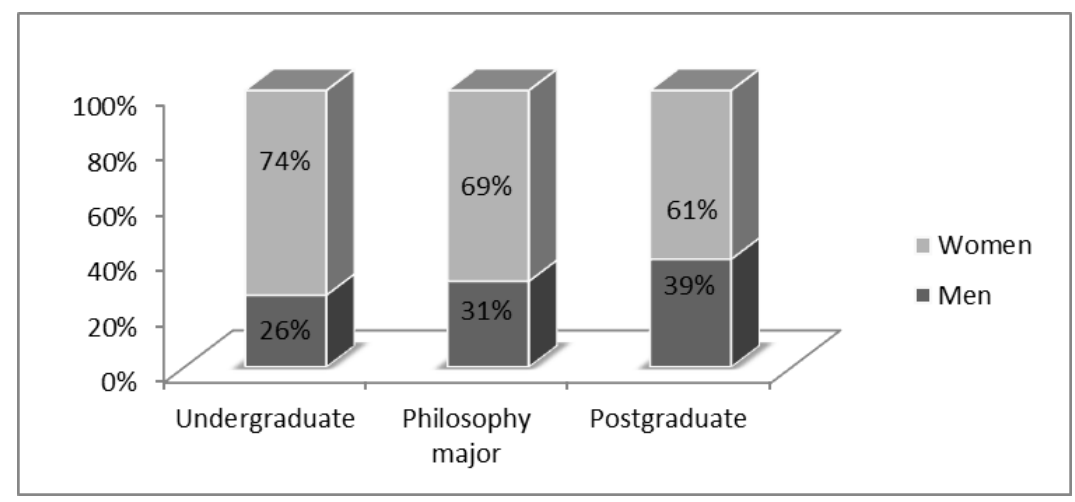

Figure 1. Gender distribution of Philosophy students per level of study

Regarding the level of familiarity with the concept of argument as standardly taught in introductory courses to logic and critical thinking, questionnaire answers indicate that students seem not to respond in the expected way to questions concerning the concept and structure of an argument, although it is the most basic tool of philosophical thinking and reasoning (see Table 1). Only $33 \%$ of all students chose the expected definition ('at least one premise and a conclusion'). The second most popular response ('at least two fundamental truths and one conclusion'), though wrong, seems closer to the expected answer. This reference to fundamental truths appears to create confusion. It seems that students are 
assuming that for something to constitute an argument it must rely on true premises, thus equating argument with sound argument. So, confusion is possibly detected between the concepts of 'soundness' and 'truth' (of premises) with students overlooking the fact that the two have a different object of reference.

Table 1. An argument consists of (only one option):

\begin{tabular}{lll}
\hline Answer & Frequency & Valid \% \\
\hline N/A & 18 & 2,5 \\
At least one hypothesis and one conclusion & 103 & 14,1 \\
Many premises and corresponding conclusions & 181 & 24,8 \\
At least one premise and one conclusion & 239 & 32,7 \\
At least two fundamental truths and one conclusion 190 & 26,0 \\
Total & 731 & 100,0 \\
\hline
\end{tabular}

Table 2. (Provided that the Socialist Party and Conservative Party are different political parties) If the Socialist Party governed in 1983, then the Conservative Party was the Official Opposition in 1983. The Conservative Party was the Official Opposition in 1983. Therefore, the Socialist Party governed in 1983. This argument is:

\begin{tabular}{lll}
\hline Answer & Frequency & Valid \% \\
\hline N/A & 8 & 1,1 \\
Valid & 203 & 27,8 \\
Valid and Fallacy & 1 &, 1 \\
Sound & 163 & 22,3 \\
Sound and Fallacy & 1 &, 1 \\
Invalid & 119 & 16,3 \\
Invalid and Fallacy & 3 &, 4 \\
Fallacy & 233 & 31,9 \\
Total & 731 & 100,0 \\
\hline
\end{tabular}


Table 3. All horses are blue. All blue (beings) fly. Consequently all horses fly. This argument is:

\begin{tabular}{lll}
\hline Answer & Frequency & Valid \% \\
\hline N/A & 9 & 1,2 \\
Valid & 163 & 22,3 \\
Valid and Fallacy & 2 &, 3 \\
Sound & 97 & 13,3 \\
Sound and Invalid & 1 &, 1 \\
Sound and Fallacy & 1 &, 1 \\
Invalid & 241 & 33,0 \\
Invalid and Fallacy & 1 &, 1 \\
Fallacy & 216 & 29,5 \\
Total & 731 & 100,0 \\
\hline
\end{tabular}

This confusion is evident also in the findings concerning the identification of the type of an argument. In general, answers to two questions of this kind attracted low percentages of correctness (see Tables $2 \& 3$ ) (Note 5). In the case of an invalid argument, students seem to recognize something is wrong with this syllogism, but they cannot pinpoint what exactly. Alternatively, they cannot clarify the meaning of the terms 'invalid' and 'logical fallacy'. The same seems to apply to the next question. Most students considered the argument 'invalid' even though it was valid (third in line answer with 22.3\%). As expected, the second most popular answer, with a relatively small difference, was 'logical fallacy' which could be explained if we consider that in students' minds these two concepts are overlapping.

Regarding the responses to the classical definition of knowledge as taught in introductory courses recorded level we see that the most popular answer $(33,2 \%)$ is that everything is knowledge (see Appendix, Table 1). This indicates confusion in the mind of students as to the exact definition of the concept. Students proceed to a general conceptualization of 'knowledge'. They seem to realize the importance of it, by identifying it with everything, but they are not able to 'put into practice' the 
mentioned concept. Quite interesting is also the second in response rate answer that identifies knowledge with experience (14,1\%). This seems again obvious, but it also shows a lack of concreteness of the concept's domain and an inability to detach oneself from its empirical/personal intake.

As far as ethics is concerned, students chose mostly (55\%) its theoretical definition that is 'behaviour under a system of values' (see Appendix, Table 2) Interestingly, the second most popular answer as to 'what is ethics' is 'whatever anyone decides to be'. In this case, we see the prevalence of a subjective or empirical approach contrary to a universal definition. The third most popular answer is 'common culture' which seems the most obvious and perhaps the most convenient.

\subsection{Research Question A}

In light of the above, research question A does not seem to be answered in the affirmative. The majority of the students who participated in the study were neither able to choose the expected definition of argument, nor able to classify it appropriately as sound, valid, invalid or fallacy. In fact, in this kind of questions students had very low success rates, regardless of University or Faculty. Thus, philosophy students do not seem to absorb the concepts of sound, valid, invalid and fallacy as taught in the classroom.

As far as knowledge is concerned answers indicate that students relate mostly knowledge with non-philosophical (pre-theoretical) views. The most popular answer was "everything" by $33 \%$, while the classical definition of knowledge ('justified true belief') was chosen only by $14 \%$ of the sample. In both Philosophy undergraduates (28\%) and postgraduate students (31\%), the classical definition of 'knowledge' had a high rate compared to that of all students, but lower than expected. Furthermore, the majority of those who had not dealt with philosophy in the past (29\%) answered 'everything', while 16\% 'experience' (the expert definition was chosen by $14 \%$ ). This finding provides the common sense conceptualization of 'knowledge', since those who had not dealt with philosophy could express and represent common sense. If intuitions 
are spontaneous judgments (see Weinberg, Nichols et al.) or 'just what anyone would say if asked her opinion', within the context of this study, they are expressed by the answers of this class of students.

In the case of ethics, the majority of students, that is $55 \%$, chose the theoretical definition. This definition displayed very high rates both in Philosophy graduates and postgraduate students. Namely, $66 \%$ of graduate students chose "behaviour under a system of values" while in undergraduates the figure reached $72 \%$. This could be explained by the fact that this definition seems closer to common sense. This is confirmed by the fact that $50 \%$ of the students who reported that they have never dealt in the past with philosophy chose the experts' definition of 'ethics'. (Note 6)

So, the classical definition of 'knowledge' as elaborated in the classroom does not coincide with its common-sense conceptualization. The opposite seems to be the case in the conceptualization of 'ethics'

\subsection{Research Question A1}

On research question A1, concerning the preconditions of the transition, we first investigated the correlation between semester and rate of textbook-based answers. Results concerning 'knowledge' and 'ethics' are as follows:

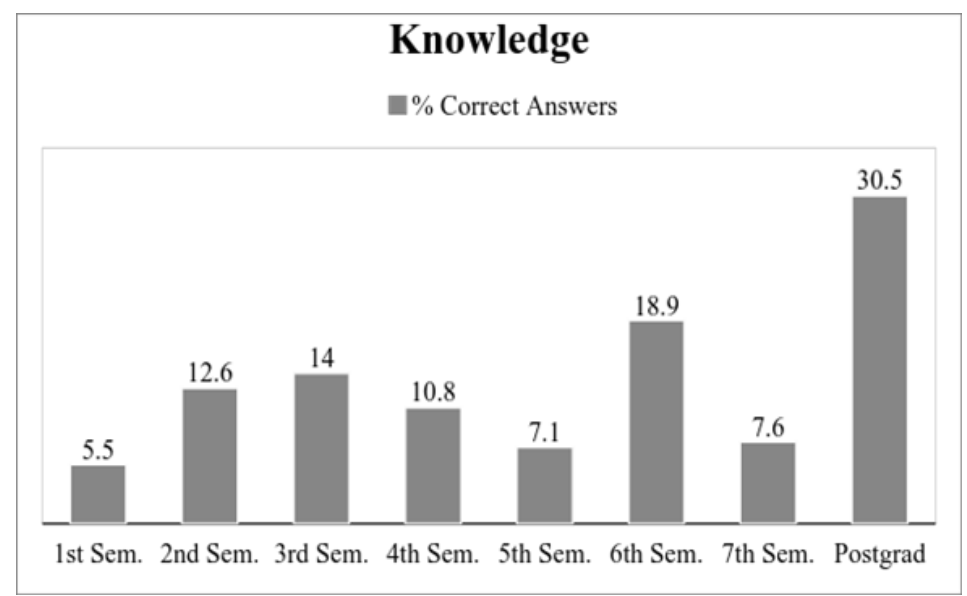

Figure 2. Percentages of textbook answers per semester 
In all semesters the expected, following the taught material, answer on knowledge gathered quite low percentages. Except for Postgraduates, in all the other semesters the answer with the highest response rate was that 'everything is knowledge'. This option gathered a very high percentage every time. As far as novices are concerned the success rate $(5,5 \%)$ was expected to below. Furthermore, a decline in expected answers is also recorded in the 4th and 5th semester and also in the 7th. Should this finding indicate a possible absence of a stimulus in the educational process that could preserve the knowledge gained in its early stages? Well, it is possible. But there might be another explanation: In non-philosophical Faculties, the optional course of Philosophy is taught mainly in higher semesters (i.e. 4th, 5th or 7th), so we have novices, not experts in higher semesters. Therefore, this deceleration may be due to the introduction of novices in higher semesters, which contradicts our main premise, i.e. the higher semester the more expertise. This possibility was investigated as follows. Since in purely Philosophical Faculties the difficulty of courses per semester is escalating, we chose to examine whether expected answers there follow a similar non-scalar pattern. Analysis revealed that even students of Philosophy Faculties apply common sense conceptualizations, instead of refining them, as semesters go by. Since in these cases there are no novices in higher semesters, it could be argued that a more likely explanation seems the one mentioned above, namely the absence or loss of a stimulus within the educational process.

Regarding the concept of ethics in all semesters, the textbook answer was the most prevalent. Particularly high percentage was recorded in the 4th semester where it reached $71 \%$ as well as in postgraduates where it rose to $66 \%$. Noteworthy is the particular high percentage $(52.7 \%)$ of novices in the definition of 'ethics'. This could be explained by the fact that 'ethics' as a concept is used more in everyday social interaction. Finally, there is a decline in expected answers in the 6th semester which could be explained again through the absence of a stimulus in the educational process, but it is less than that concerning the concept of 'knowledge'. 
The second precondition was course identity. For that purpose we categorized the strict philosophical undergraduate courses into 4 general categories, based on their syllabus: a) Epistemology, b) Ethics, c) History of Philosophy, and d) Introduction to Philosophy. The objective was to ascertain whether, for example, students attending Epistemology courses have made the transition from pre-instructional conception to textbook definitions more than undergraduates attending other philosophy courses. Table 4 presents the percentages of the most popular answers concerning 'knowledge'.

Table 4. What is 'Knowledge'?

\begin{tabular}{l|l|l|l|l}
\hline & Epistemology Courses & $\begin{array}{l}\text { Ethics } \\
\text { Courses }\end{array}$ & $\begin{array}{l}\text { History of } \\
\text { Philosophy } \\
\text { Courses }\end{array}$ & $\begin{array}{l}\text { Introduction } \\
\text { to } \\
\text { Philosophy } \\
\text { Courses }\end{array}$ \\
\hline $\begin{array}{l}\text { Experience } \\
\text { A true belief }\end{array}$ & 9.6 & 14.4 & 19.4 & 19.2 \\
$\begin{array}{l}\text { A justified } \\
\text { belief }\end{array}$ & 12.0 & 6.6 & 5.8 & 6.1 \\
$\begin{array}{l}\text { A justified true } \\
\text { belief }\end{array}$ & 22.4 & 9.4 & 12.6 & 11.1 \\
$\begin{array}{l}\text { Impossible to } \\
\text { be defined }\end{array}$ & 5.6 & 11 & 13.6 & 12.1 \\
Everything & 29.6 & 11 & 4.9 & 7.1 \\
\hline
\end{tabular}

Table 5 presents the percentages of the most popular answers concerning 'ethics'. 
Table 5. What is 'Ethics'?

\begin{tabular}{|c|c|c|c|c|}
\hline & $\begin{array}{l}\text { Epistemology } \\
\text { Courses }\end{array}$ & Ethics Courses & $\begin{array}{l}\text { History of } \\
\text { Philosophy } \\
\text { Courses }\end{array}$ & $\begin{array}{l}\text { Introduction } \\
\text { to } \\
\text { Philosophy } \\
\text { Courses }\end{array}$ \\
\hline Common culture & 6.4 & 11.1 & 2.9 & 7.1 \\
\hline Does not exist & 6.4 & 3.9 & 5.9 & 3 \\
\hline A personal choice & 15.2 & 22.2 & 32.4 & 26.3 \\
\hline $\begin{array}{l}\text { Law and political } \\
\text { power }\end{array}$ & 1.6 & 1.7 & 2.9 & 3 \\
\hline $\begin{array}{l}\text { Behaviour under } \\
\text { a system of } \\
\text { values }\end{array}$ & 62.4 & 55.6 & 44.1 & 51.5 \\
\hline $\begin{array}{l}\text { What benefits the } \\
\text { most }\end{array}$ & 4.8 & 3.9 & 5.9 & 4 \\
\hline
\end{tabular}

As far as 'knowledge' is concerned (Table 4) we see that the 'textbook definition' has been answered in a higher percentage by those who attended epistemology courses. And that was something expected. The most popular answer here, but also in all categories is "everything", although in the first category it holds the lowest percentage. In addition to the misconception of 'everything', we also have a high percentage of the misconception 'experience', especially in non-strictly epistemological courses. Now, concerning 'ethics' (Table 5), the formal definition has been more widely answered in epistemology courses than in ethics and it is the most popular answer overall. The basic misconceptions here are "a personal choice" and "common culture". One might say that in the case of 'knowledge' teaching seems to have "dismantled" to a greater extent the misconceptions of those attending epistemology courses.

For the concept of knowledge, the p-value is >.05 (statistically insignificant), but the adjusted standardized residuals are $>2$ in Epistemology courses, which shows that students there provided to a greater extent the textbook definition compared to other courses.

For the concept of Ethics, the p-value indicates a marginal statistically significant difference (.048). Based on adjusted standardized 
residuals, those who attended epistemology courses chose textbook definition more than others, and those who attended history of philosophy chose the textbook definition comparatively less (see also Annex Tables $3 \& 4$ for a cross-tabulation analysis between courses and answers).

\subsection{Research Question A2}

As far as research question A2 is concerned, we made the following working assumption: the shaping of students' intuitions about the concepts in question depends on their degree of familiarity with philosophy. Table 6 presents participants' answers on this matter.

Table 6. What is your degree of familiarity with Philosophy?

\begin{tabular}{lll}
\hline Answer & Frequency & Valid \% \\
\hline N/A & 3 &, 4 \\
Very low & 71 & 9,7 \\
Low & 188 & 25,7 \\
Middle & 350 & 47,9 \\
High & 100 & 13,7 \\
Very high & 19 & 2,6 \\
Total & 731 & 100,0 \\
\hline
\end{tabular}

Most respondents believe they are modestly familiar with philosophy. But are they? Do students' pre-educational or outside curriculum opinions weight more and persist in the shaping of their' intuitions? And is their familiarity with basic philosophical concepts depended on whether they are studying Philosophy or are simply taught Philosophy during their studies? To explore these issues, we decided to divide the sample into three categories:

1. The first category includes data collected from Schools/Faculties where Philosophy courses represent a small part of the curriculum (e.g. from School of Applied Mathematical and Physical Sciences of NTUA, the Hellenic Open University and 
the School of Humanities and Social Sciences in the Department of Educational Sciences and Early Childhood Education, University of Patras).

2. The second category includes data collected from schools in which Philosophy courses constitute a large part of the curriculum (e.g. the Department of Philosophy and History of Science and the Inter-University graduate program History and Philosophy of Sciences and Technology).

3. The third category includes data collected from Philosophical Faculties (Faculty of Philosophy, Pedagogy and Psychology, University of Athens, Department of Philosophy, Education and Psychology, University of Ioannina, in Postgraduate program of Philosophy of the University of Crete and Postgraduate program of Philosophy of the University of Patras).

The above categorization rested on the assumption that the students of the third category (i.e. the students of Philosophical Faculties) would be more familiar with Philosophy than the students of the first and the second category.

Table 7: Degree of self-reported familiarity per category of students.

\begin{tabular}{lllllll}
\hline $\begin{array}{l}\text { Category of Very low } \\
\text { philosophy } \\
\text { students }\end{array}$ & $\begin{array}{l}\text { Logree of } \\
\text { familiarity }\end{array}$ & $\begin{array}{l}\text { degree of } \\
\text { familiarity }\end{array}$ & $\begin{array}{l}\text { Moderate } \\
\text { degree of } \\
\text { familiarity }\end{array}$ & $\begin{array}{l}\text { High } \\
\text { degree of } \\
\text { familiarity }\end{array}$ & $\begin{array}{l}\text { Very high } \\
\text { degree of } \\
\text { familiarity }\end{array}$ & N/A \\
\hline $1^{\text {st }}$ & $19 \%$ & $34 \%$ & $38 \%$ & $7 \%$ & $2 \%$ & 0 \\
$2^{\text {nd }}$ & $9 \%$ & $24 \%$ & $49 \%$ & $15 \%$ & $3 \%$ & 0 \\
$3^{\text {rd }}$ & $7 \%$ & $24 \%$ & $51 \%$ & $15 \%$ & $2 \%$ & $1 \%$ \\
\hline
\end{tabular}

The categorization was further confirmed by the findings presented in Table 7. More specifically, 53\% of students belonging to the first category reported low or very low degree of familiarity with philosophy, $33 \%$ of students belonging to the second category reported low or very low degree and $31 \%$ of students belonging to the third category reported low or very low degree of familiarity with philosophy. 
Also, students of Philosophical Faculties stated a quite high degree (the rates of high and very high degree leapt in categories 2 and 3).

But are they indeed more familiar? The following table shows that this does not seem to be the case and in fact that on many questions the first category is doing better than the others.

Table 8: Percentage of textbook answers to philosophical questions per category of students.

\begin{tabular}{|c|c|c|c|}
\hline Question & $1^{\text {st }}$ Category & $2^{\text {nd }}$ Category & $3^{\text {rd }}$ Category \\
\hline $\begin{array}{l}\text { 1. 'Argument' } \\
\text { definition }\end{array}$ & $28 \%$ & $35 \%$ & $33 \%$ \\
\hline $\begin{array}{l}\text { 2. 'Argument' type } \\
\text { (1) }\end{array}$ & $25 \%$ & $15 \%$ & $14 \%$ \\
\hline $\begin{array}{l}\text { 3. 'Argument' type } \\
\text { (2) }\end{array}$ & $23 \%$ & $24 \%$ & $21 \%$ \\
\hline $\begin{array}{l}\text { 4. 'Knowledge' } \\
\text { definition }\end{array}$ & $14 \%$ & $10 \%$ & $17 \%$ \\
\hline 5. 'Ethics' definition & $57 \%$ & $51 \%$ & $57 \%$ \\
\hline Total $\mathrm{A}^{1}$ & $25 \%$ & $25 \%$ & $23 \%$ \\
\hline Total $\mathrm{B}^{2}$ & $29 \%$ & $27 \%$ & $28 \%$ \\
\hline
\end{tabular}

1. Total $\mathrm{A}$ is the mean score of questions concerning 'argument' (1-3).

2. Total B is the mean score of questions concerning 'argument', 'knowledge' and 'ethics' (1-5).

Specifically, Table 8 reflects the performance of philosophy students per category. Drawing from the data one can firstly conclude that compared to other concepts, students who belong to the first and second category seem to be more in accord with the course material about the concept of 'argument'. Within this conceptualization, students of the second and third category performed relatively well concerning the recognition of the typical form of 'argument', although percentages are objectively low. Overall, all answers seem equally shared. The first category of philosophy students gather both in total A and in total B the 
highest percentage of expected answers. Differences between the three categories are not as big as someone would expect. Generally, the rates of answers per taught material are low except for the concept of 'ethics' which is recorded just over 50\%. So, students, regardless of whether they are studying Philosophy or any other discipline that includes Philosophy in the curriculum, do absorb the concept of argument and basic philosophical concepts, such as 'knowledge' and 'ethics'.

Research question A2 concerns the role of intuitions. This particular cognitive process is very important for philosophy students/potential philosophers. Empirical findings indicate that students have not developed an intuitive ability for recognizing the truth of an established premise. Their intuitions about philosophical terms remain, in all semesters, independent of what they are taught in the class; they lack any theoretical necessity and are primarily linguistic in form. There appears to be no expert disposition guiding the conceptualization process. For example, in students' intuitional domain 'everything' seems to be the appropriate answer regarding the definition of 'knowledge'. When asked their opinion, students answer by classifying the given concepts in terms of everyday use, rather than of intellectual elaboration. Their intuitions are simply opinions, commonsensical in nature, lacking the proper degree of sophistication that a philosophical theory requires (see Lewis, 1983).

Therefore, intuitions' role seems to be that of enhancing a pretheoretical or outside curriculum treatment of concepts. And as it seems, they do not seem to allow yet an overcome from a pre-theoretical to a theoretical background. They are not specially configured for this mission, maybe because they are not receiving the necessary feedback from the teaching process. Furthermore, as can be seen in Table 4, most respondents believe they are modestly familiar with Philosophy. Students of the second and third category declare greater familiarity with Philosophy (either moderate or high or very high degree). But the percentages of expected answers do not verify this estimate. Hence, the possibility of not only a misconception about the concepts but also a misconception on their intuitions is strengthened. (Note 7)

When students are faced with in-class 'counter-intuitive material' which aims to open up a new and previously inaccessible way of 
thinking, first they need to 'soften up' their intuitions. The breadth and quality of this (educational) process depends on students' prior familiarity with the subject. Namely, familiarity that is rooted in school teaching. In answering the question of whether this early exposure to philosophy favours the efficient grasp of the concepts, data analysis revealed that: 69 out of the 103 (67\%) respondents who correctly answered the question of 'what is knowledge' have stated that they dealt with philosophy in school. Furthermore, 260 out of the $402(66 \%)$ respondents who correctly answered the question of 'what is ethics' and 152 out of the 239 (64\%) respondents who correctly answered the question of 'what is philosophical argument' have dealt with philosophy in school. In all three cases, a fairly high percentage of those who seem to grasp the corresponding concept had dealt with philosophy at school.

\section{CONCLUSION}

Findings indicate that a transition from common sense to theoretical understanding does not seem to be the case. So, either (a) the theoretical approach is inadequate or (b) how these basic concepts are taught is inadequate. If we accept the second explanation, then Philosophy should be taught at school because this seems to facilitate the necessary transition. Students already familiar with certain concepts maintain their theoretical definitions, whereas when they learn about them later at university it seems harder to make the necessary shift. Theoretical understanding seems to be determined by intuitions that have to be configured for this shift, through necessary feedback from previous teaching processes. That is explained by our data where almost two out of three students who identified the three formal definitions had dealt with philosophy at school. This is also important because it highlights the great contribution of teaching philosophy in schools (see $\mathrm{P} 4 \mathrm{C}$ program).

As shown, students fail to adequately define 'argument' and seem to be confused about concepts that characterize it (e.g. valid, sound, etc.) For 'knowledge' data indicate that students cannot distinguish the concept from its everyday language use (see for example the high identification of 'knowledge' as 'everything' or 'experience'). For 
'ethics' one main reason why its philosophical definition concentrates higher rates compared to that of 'knowledge' could be that the former is closer to common sense. Thus, Ethics could be the starting point of the learning process (see conceptual change paradigm) developed by students before instruction. Successful learning, in this respect, implies the internalization of ethical theories on the issues in question. And of course, this process should be realized also in the case of 'knowledge' and 'argument'. This is also implied by the ascertainment that students do not seem to distinguish between basic philosophical terms as taught in the classroom and their everyday language use. They are not sufficiently familiar with the theoretical definitions and hence with the concepts themselves.

Even though we hypothesized that for students the process of acquiring knowledge during their studies changes depending on the semester, in the end, there is no significant variation. Students' perception of philosophical concepts does not appear to vary significantly, relative to the semester. The novice status seems to be generally addressed among students, expressing an internally inconsistent and non-theoretically coherent way of thinking. As far as the course identity is concerned, the teaching of specific courses seems to favour the transition for specific concepts. Furthermore, there is a common pattern of misconceptions (for example, in 'ethics' is: personal choice - common culture - what benefits the most - does not exist) found in all students regardless of the course they attend.

Eventually, this research could benefit mostly those who teach philosophy. Our findings indicate that some formal definitions are closer to common sense (e.g. 'ethics') and some others aren't (e.g. 'knowledge'). Besides, all the concepts we looked at, in addition to concepts in philosophy, are also part of everyday language. This might create difficulties in the desirable transition, if similarities are not established between everyday understanding and academic understanding. How can we adapt teaching towards this goal?

- By locating core concepts in philosophy in general, and in philosophical domains, in particular, 
- By finding out what pre-instructional conceptions students have about these core concepts (our study provides some information about that),

- By using "concept maps" or even "misconception maps" to facilitate conceptual change and,

- By adapting teaching to: (a) build on pre-instructional conceptions if they are accurate and bridging the knowledge that students already have with the new knowledge professors teach, (b) challenge pre-instructional conceptions and replacing them with robust ones.

\section{REFERENCES}

Alauddin, M. \& Ashman, A. (2014). The changing academic environment and diversity in students' study philosophy, beliefs and attitudes in higher education. Higher Education Research \& Development, 33(5), 857-870, https://doi.org/10.1080/07294360.2014.890568.

Baggini, J., \& Fosl, P. S. (2010). The philosopher's toolkit: A compendium of philosophical concepts and methods (2nd edition). UK: WileyBlackwell.

Booth, J. (2006). On the mastery of philosophical concepts: Socratic discourse and the unexpected 'effect'. In J. H. F. Meyer and R. Land (Eds), Overcoming barriers to student understanding: Threshold concepts and troublesome knowledge, 173-181, Oxfordshire: Routledge.

Cato, D. (1987). Getting clearer about 'getting clearer': R. S. Peters and secondorder conceptual analysis. Journal of Philosophy of Education, 21, 2536, https://doi.org/10.1111/j.1467-9752.1987.tb00140.x.

Churchill, L. R. (1999). Are we professionals? A critical look at the social role of Bioethicists. Daedalus, 128, 253-274.

DiSessa, A. A. (1988). Knowledge in pieces. In G. Forman \& P. Pufall (Eds.), Constructivism in the computer age, 49-70, Hillsdale, NJ: Erlbaum.

Duke, E. A., Hicken, W. F., Nicholl, W. S. M., Robinson, D. B., \& Strachan, J. C. G. (Eds.) (1995). Platonis opera tomus I. Oxford: Oxford University Press.

Goldman, A. I. (2007). Philosophical intuitions: Their target, their source, and their epistemic status. Grazer Philosophische Studien, 74, 1-26, https://doi.org/10.1163/9789401204651_002. 
Herzog, A. R., \& Bachman, J. G. (1981). Effects of questionnaire length on response quality. Public Opinion Quarterly, 45, 549-559.

Iliadi, S., Theologou, K. \& Stelios, S. (2019). Are University Students Who Are Taking Philosophy Courses Familiar with the Basic Tools for Argument? Teaching Philosophy, 42, 3, 197-220. https://doi.org/10.5840/teachphil2019726106

Jackson, F. (1998). From Metaphysics to Ethics: A defence of conceptual analysis. Oxford: Clarendon Press.

Koutoungos, A. (2008). Between the moral and the rational. Athens: Papazissis Publishers.

Laverty, M. (2009). Learning our concepts. Journal of Philosophy of Education, 43, 27-41, https://doi.org/10.1111/j.1467-9752.2010.00753.x.

Lewis, D. (1983). Philosophical papers: Volume I. New York: Oxford University Press.

Locke, J. (1694/1975). Of identity and diversity (Chapter XXVII of An essay concerning human understanding). In J. Perry (Ed.), Personal identity, 33-52. Berkeley: University of California Press.

Meyer, J. H. F. \& Land, R. (2003a). Threshold concepts and troublesome knowledge: linkages to ways of thinking and practising within the disciplines. In C. Rust (Ed.), Improving student learning: Improving student learning theory and practice - Ten years on. Oxford: OCSLD.

Murphy, P. K. \& Alexander, P. (2008). The role of knowledge, beliefs, and interest in the conceptual change process: A synthesis and meta-analysis of the research. In S. Vosniadou (Ed.), International handbook of research on conceptual change, 583-616. New York: Routledge.

Prinz, J., J. (2007). Empirical philosophy and experimental philosophy. In J. Knobe, \& S. Nichols (Eds.), Experimental Philosophy, 189-208. New York: Oxford University Press.

Pust, J. (2019). Intuition. In E. N. Zalta (Ed.), The Stanford Encyclopedia of Philosophy (URL: <https://plato.stanford.edu/archives/sum2019/entries/ intuition/>, Retrieved: January, 8th 2020).

Rusanen, A.M., Lappi, O., Honkela, T., \& Nederström, M. (2008). Conceptual coherence in philosophy education-Visualizing initial conceptions of philosophy students with self-organizing maps. In B. C. Love, K. McRae, \& V. M. Sloutsky (Eds.), Proceedings of the 30th annual conference of the cognitive science society, 64-70. Austin, TX: Cognitive Science Society.

Salkind, N. (Ed.). (2007). Encyclopedia of measurement and statistics. Thousand Oaks, CA: SAGE Publications. 
Salzberger, R. P. (1997). Ethics outside the limits of Philosophy: Ethical inquiry at Metropolitan State University. Teaching Philosophy 20(2), 169-191, https://doi.org/10.5840/teachphil199720220.

Sheppard, C. and Gilbert, J. (1991). Course design, teaching method and student epistemology. Higher Education, 22, 229-249, https://doi.org/10.1007/ bf00132289.

Vosniadou, S., \& Brewer, W. F. (1992). Mental models of the Earth: A study of conceptual change in childhood. Cognitive Psychology, 24, 535-585, https://doi.org/10.1016/0010-0285(92)90018-w.

Weinberg, J. M., Nichols, S., \& Stich, S. (2001). Normativity and epistemic intuitions. Philosophical Topics, 2, 429-460, https://doi.org/10.5840/ philtopics2001291/217.

Wortham, S. (2015). Clearing away assumptions through philosophy and research. Studies in Philosophy and Education, 34, 125-136, https://doi.org/10.1007/s11217-014-9419-2. 


\section{Notes}

Note 1. This approach resembles the theory of 'threshold concepts'. A threshold concept can be considered as akin to a portal, opening up a new and previously inaccessible way of thinking about something. It represents a transformed way of understanding, or interpreting, or viewing something without which the learner cannot progress. (Meyer and Land 2003a, p. 412). Philosophy, as a doctrine, is rife with that theoretical consideration. Any question of how best to teach philosophy is intimately related to the question of how best to facilitate students' mastery of these concepts (Booth, 2006, p. 173). Once students have mastered a philosophical threshold concept, their viewpoint on the subject matter will be transformed. This new understanding that a learner has 'interferes' with her earlier outlook, and is colouring her opinions and understanding of both new and previously acquired material. For example, before grasping the concept of 'knowledge', a philosophy student is limited to a vague conception of its content as being either everything one believes as true or any specialization. Once she grasps that specific notion, a third position opens up, namely the idea that its contents might be all beliefs that are justifiable and true.

Note 2. To address any limitations, we attempted to enhance the diversity and representativeness of our sample, by designing the following actions: i) Questionnaires were completed at different time, day and classrooms and in different Philosophy courses, ii) Our sample involved students from all semesters, iii) Our sample included students from different universities and in any case we pursued that all institutions in which there is a Philosophy department would be included, and iv) We sought to include in our sample not only students studying Philosophy, but also students attending Philosophy courses while studying other academic subjects.

Note 3. The Human Subjects Protection Tutorial of the Institutional Review Board is available: http://www.irb.vt.edu/documents/downloadable_tutorial.pdf (Retrieved: January, 8th 2020).

Note 4 . We chose not to include 'argument' in this analysis because its definition refers primarily to its structure, making it a more functional than theoretical concept.

Note 5. Correct answers are those that have been formulated by experts and are taught in the curriculum.

Note 6. Besides what is presented here, the questionnaire included also general and demographic questions, one of which concerned any previous engagement of students with Philosophy. 
Note 7. One could ingeniously argue that this point could be used in the debate between supporters of armchair philosophy and representatives of experimental philosophy. This ascertainment is further supported by the strong likelihood that future representatives of both approaches are among respondents (for an overview of both fields see Prinz, 2007)! 


\section{Appendix}

Table 1. Knowledge is (only one option):

\begin{tabular}{lll}
\hline Answer & \multicolumn{2}{l}{ Frequency Valid \% } \\
\hline N/A & 4 &, 5 \\
Experience & 103 & 14,1 \\
Everything & 243 & 33,2 \\
A belief & 16 & 2,2 \\
A true belief & 49 & 6,7 \\
A justified belief & 93 & 12,7 \\
Anything that can be experimentally verified & 44 & 6,0 \\
A justified true belief & 103 & 14,1 \\
Impossible to be defined & 58 & 7,9 \\
Whatever the ruling ideology defines as & 12 & 1,6 \\
knowledge & 6 &, 8 \\
What scientists decide it to be & 731 & 100,0 \\
Total &
\end{tabular}

Table 2. Ethics is (only one option):

\begin{tabular}{lll}
\hline Answer & Frequency & Valid \% \\
\hline N/A & 6 &, 8 \\
The religion of a community & 7 & 1,0 \\
Whatever benefits the most & 34 & 4,7 \\
Common culture & 58 & 7,9 \\
Sexual behaviour & 7 & 1,0 \\
The power of money & 2 &, 3 \\
Ethics does/do not exist & 30 & 4,1 \\
Personal choice & 165 & 22,6 \\
Law and political power & 17 & 2,3
\end{tabular}




$\begin{array}{lll}\text { Behaviour under a system of values } & 402 & 55,0 \\ \text { The law of the fittest } & 3 & , 4 \\ \text { Total } & 731 & 100,0\end{array}$

Table 3. Course * Answer Crosstabulation

\begin{tabular}{|c|c|c|c|c|c|}
\hline & & & Studen & nswer & \\
\hline & & & Other & Textbook & Total \\
\hline Course & Epistem & Count & 111 & 15 & 126 \\
\hline & & Expected Count & 116.3 & 9.7 & 126.0 \\
\hline & & $\%$ within Course & $88.1 \%$ & $11.9 \%$ & $100.0 \%$ \\
\hline & & $\begin{array}{l}\text { Adjusted } \\
\text { Residual }\end{array}$ & -2.1 & 2.1 & \\
\hline & Ethics & Count & 169 & 12 & 181 \\
\hline & & Expected Count & 167.1 & 13.9 & 181.0 \\
\hline & & $\%$ within Course & $93.4 \%$ & $6.6 \%$ & $100.0 \%$ \\
\hline & & $\begin{array}{l}\text { Adjusted } \\
\text { Residual }\end{array}$ & .7 & -.7 & \\
\hline & $\mathrm{HoP}$ & Count & 97 & 6 & 103 \\
\hline & & Expected Count & 95.1 & 7.9 & 103.0 \\
\hline & & $\%$ within Course & $94.2 \%$ & $5.8 \%$ & $100.0 \%$ \\
\hline & & $\begin{array}{l}\text { Adjusted } \\
\text { Residual }\end{array}$ & .8 & -.8 & \\
\hline & Intro & Count & 93 & 6 & 99 \\
\hline & & Expected Count & 91.4 & 7.6 & 99.0 \\
\hline & & $\%$ within Course & $93.9 \%$ & $6.1 \%$ & $100.0 \%$ \\
\hline & & $\begin{array}{l}\text { Adjusted } \\
\text { Residual }\end{array}$ & .7 & -.7 & \\
\hline Total & & Count & 470 & 39 & 509 \\
\hline & & Expected Count & 470.0 & 39.0 & 509.0 \\
\hline & & $\%$ within Course & $92.3 \%$ & $7.7 \%$ & $100.0 \%$ \\
\hline
\end{tabular}


Chi-Square Tests

$\begin{array}{llll} & \text { Value } & \text { df } & \text { Asymptotic Significance (2-sided) } \\ \begin{array}{l}\text { Pearson Chi- } \\ \text { Square }\end{array} & 4.328^{\mathrm{a}} & 3 & .228 \\ \text { Likelihood Ratio } & 3.979 & 3 & .264 \\ \text { N of Valid Cases } & 509 & & \end{array}$

a. 0 cells $(0.0 \%)$ have expected count less than 5 . The minimum expected count is 7.59 .

Table 4. Course * Answer Crosstabulation

\begin{tabular}{|c|c|c|c|c|c|}
\hline & & & \multicolumn{3}{|c|}{ Students' Answer } \\
\hline & & & Other & Textbooks & Total \\
\hline \multirow[t]{15}{*}{$\overline{\text { Course }}$} & Epistem & Count & 48 & 78 & 126 \\
\hline & & Expected Count & 58.2 & 67.8 & 126.0 \\
\hline & & $\%$ within Course & $38.1 \%$ & $61.9 \%$ & $100.0 \%$ \\
\hline & & $\begin{array}{l}\text { Adjusted } \\
\text { Residual }\end{array}$ & -2.1 & 2.1 & \\
\hline & Ethics & Count & 81 & 100 & 181 \\
\hline & & Expected Count & 83.6 & 97.4 & 181.0 \\
\hline & & $\%$ within Course & $44.8 \%$ & $55.2 \%$ & $100.0 \%$ \\
\hline & & $\begin{array}{l}\text { Adjusted } \\
\text { Residual }\end{array}$ & -.5 & .5 & \\
\hline & $\mathrm{HoP}$ & Count & 58 & 45 & 103 \\
\hline & & Expected Count & 47.6 & 55.4 & 103.0 \\
\hline & & $\%$ within Course & $56.3 \%$ & $43.7 \%$ & $100.0 \%$ \\
\hline & & $\begin{array}{l}\text { Adjusted } \\
\text { Residual }\end{array}$ & 2.3 & -2.3 & \\
\hline & Intro & Count & 48 & 51 & 99 \\
\hline & & Expected Count & 45.7 & 53.3 & 99.0 \\
\hline & & $\%$ within Course & $48.5 \%$ & $51.5 \%$ & $100.0 \%$ \\
\hline
\end{tabular}




\begin{tabular}{|c|c|c|c|c|}
\hline & $\begin{array}{l}\text { Adjusted } \\
\text { Residual }\end{array}$ & .5 & -.5 & \\
\hline \multirow[t]{3}{*}{ Total } & Count & 235 & 274 & 509 \\
\hline & Expected Count & 235.0 & 274.0 & 509.0 \\
\hline & $\%$ within Course & e $46.2 \%$ & $53.8 \%$ & $100.0 \%$ \\
\hline
\end{tabular}

Chi-Square Tests

Value df Asymptotic Significance (2-sided)

$\begin{array}{llll}\text { Pearson Chi- } & 7.927^{\mathrm{a}} & 3 & .048\end{array}$

Square

Likelihood Ratio $7.955 \quad 3 \quad .047$

$\mathrm{N}$ of Valid Cases 509

a. 0 cells $(0.0 \%)$ have expected count less than 5 . The minimum expected count is 45.71 .

\section{Copyrights}

Copyright for this article is retained by the author(s), with first publication rights granted to the journal.

This is an open-access article distributed under the terms and conditions of the Creative Commons Attribution license (http://creativecommons.org/ licenses/by/3.0/). 


\section{SPIRIDON STELIOS}

Nacionalni tehnički univerzitet u Atini, Odsek za humanističke nauke, društvene nauke i pravo, Grčka

KOSTAS TEOLOGU

Nacionalni tehnički univerzitet u Atini, Odsek za humanističke nauke, društvene nauke i pravo, Grčka

SIMONI ILIADI

Nacionalni tehnički univerzitet u Atini, Odsek za humanističke nauke, društvene nauke i pravo, Grčka

ELENI MANOLAKAKI

Nacionalni i kapodistrijski univerzitet u Atini, Odsek za istoriju i filozofiju nauke, Grčka

\section{ARGUMENT, SAZNANJE I ETIKA: RAZUMEVANJE KLJUČNIH POJMOVA U FILOZOFIJI EMPIRIJSKOM STUDIJOM O STUDENTIMA GRČKIH UNIVERZITETA}

Sažetak: Empirijska studija sprovedena je tako što se merio stepen do kojeg je shvatanje ključnih filozofskih pojmova (kakvi jesu ,,argument“,,,saznanje“ i „etika“) oblikovano građom koja se predaje u učionici. Mera u kojoj se prešlo s prednastavnih koncepcija na udžbeničke formulacije istraživana je korišćenjem novog upitnika. Zaključci upućuju na to da studenti, načelno, zadržavaju svoja predteorijska shvatanja tih termina. U ovom okviru, neke formalne definicije bliže su zdravom razumu (npr. „etika“), dok neke druge no to nisu (npr. „saznanje“). Dalje, vrednovana je uloga intuicije u tom procesu, što vodi do tvrdnje da prethodni filozofski susreti izgleda da igraju presudnu ulogu $u$ određivanju stvarnog shvatanja.

Ključne reči: prednastavne koncepcije, učenje filozofije, nastava filozofije, intuicija

Primljeno: 1.3 .2020 .

Prihvaćeno: 6.5.2020. 